\title{
Wiggle-match radiocarbon dating of the Taupo eruption
}

\author{
Alan G. Hogg ${ }^{1 \star}$, Colin J.N. Wilson ${ }^{2}$, David J. Lowe ${ }^{3}$, Chris S.M. Turney ${ }^{4}$, Paul White ${ }^{5}$, Andrew M. Lorrey ${ }^{6}$, \\ Sturt W. Manning ${ }^{7}$, Jonathan G. Palmer ${ }^{4}$, Sarah Bury ${ }^{8}$, Julie Brown ${ }^{8}$, John Southon ${ }^{9}$ \& Fiona Petchey ${ }^{1}$ \\ ARISING FRom Richard N. Holdaway et al. Nature Communications https://doi.org/10.1038/s41467-018-06357-0 (2018)
}

T he Taupo eruption ${ }^{1}$ deposit is an isochronous marker bed that spans much of New Zealand's North Island and predates human arrival ${ }^{2}$. Holdaway et $\mathrm{al}^{3}{ }^{3}$ (HDK18 hereafter) propose that the current Taupo eruption date is inaccurate, and that the eruption occurred decades to two centuries after the published wiggle-match estimate of $232 \pm 10 \mathrm{CE}(2 \mathrm{SD})^{4}$ derived from a tanekaha (Phyllocladus trichomanoides) tree at the Pureora buried forest site ${ }^{5,6}$. HDK18 propose that trees growing at Pureora (and other near-source areas) that were killed and buried by the climactic ignimbrite event were affected by ${ }^{14} \mathrm{C}$-depleted (magmatic) $\mathrm{CO}_{2}$. HDK18's proposal utilises a wide range of published ${ }^{14} \mathrm{C}$ data, but their work results in assertions that are implausible. Four parts to their hypothesis are considered here.

The ${ }^{14} \mathrm{C}$-date compilation used by HDK18 to claim that the Pureora and other near-source dates are anomalously old is flawed. The dataset used to construct HDK18's Fig. 1 is incomplete: at least 18 additional ages (including short-lived leaf and seed material) ${ }^{7}$ on Taupo eruptives from various sites (e.g., ref. ${ }^{8}$ ) were not included. Most of the dates used in the figure have large errors and calibrated mean values extend between $650 \mathrm{CE}$ and $-100 \mathrm{CE}$, making them statistically indistinguishable and undermining the significance of any purported best fit correlation. This wide range of ages was a principal reason why wiggle-match dating of the Pureora buried forest logs was undertaken ${ }^{4}$. Ages in HDK18 (Supplementary Table S1), used to infer an age-vs.-distance relationship, represent a collation of data obtained over more than half-a-century from different laboratories, using differing dating methods (i.e., solid-carbon, gas proportional counting, liquid scintillation spectroscopy, accelerator mass spectrometry), differing pretreatment regimes (i.e., no pretreatment, acid-base-acid pretreatment, cellulose extraction), and differing age calculation procedures (i.e., non-Conventional Radiocarbon Age (CRA) vs. CRA). Indeed, many of the apparently anomalous oldest reported ages are from analyses dating to the $1950 \mathrm{~s}-60 \mathrm{~s}^{9}$. Even with modern techniques and consistent protocols, there remain inter-laboratory differences that preclude simple collation of ${ }^{14} \mathrm{C}$ data sets. For example, Hogg et al. ${ }^{4}$ (Fig. 4) show that the Rafter and Waikato laboratory analyses, undertaken on wood derived from the same tanekaha tree-ring chronology ${ }^{6}$, have a systematic offset, with Rafter analyses, which dominate HDK18 (Supplementary Table S1), on average 40 years younger. Of critical importance, the Waikato study circumvented such laboratory bias by analysing a 250 -year series of contiguous decadal ${ }^{14} \mathrm{C}$ dates from the Pureora tanekaha tree and wiggle-matched them against known calendar-age kauri (Agathis australis) to derive a date for the eruption of $232 \pm 10 \mathrm{CE}^{4}$.

Relationships between the dates in HDK18's Supplementary Table S1 (36 values), Supplementary Fig. S2 (45 values) and the Taupo eruption deposits are also unclear, with the stratigraphic context often lacking, impairing the value of the age estimates. An example of best practice is from a section ${ }^{10}$ at Kaipo bog, far removed from any possible magmatic ${ }^{14} \mathrm{C}$ contamination ${ }^{3}$, which incorporates the Taupo eruption deposits. Here, stratigraphically ordered, independent age points $\left(37\right.$ local ${ }^{14} \mathrm{C}$ ages and 16 tephrochronological ages) were used ${ }^{10}$ to derive dates (not cited by HDK18) for the Taupo layer of $231 \pm 12$ CE (OxCal) and $251 \pm 51 \mathrm{CE}$ with a weighted-mean date of $240 \mathrm{CE}$ (Bacon-software-derived), statistically identical to the Pureora wiggle-match estimate ${ }^{4}$.

The potential impact of injected ${ }^{14} \mathrm{C}$-depleted magmatic $\mathrm{CO}_{2}$ on reservoir ages in Lake Taupo (and the Waikato River draining the lake) is documented ${ }^{11}$. HDK18 present ${ }^{14} \mathrm{C}$ dates of organic materials from this area, i.e., within $60 \mathrm{~km}$ of the Taupo eruption source (HDK18, Fig. 3), and propose that these dates are biased towards older ages by $\mathrm{CO}_{2}$ degassed from groundwater. We discount this proposition at the Pureora forest site for several

\footnotetext{
${ }^{1}$ Radiocarbon Dating Laboratory, University of Waikato, Hamilton, New Zealand. ${ }^{2}$ School of Geography, Environment and Earth Sciences, Victoria University, Wellington, New Zealand. ${ }^{3}$ School of Science (Earth Sciences), University of Waikato, Hamilton, New Zealand. ${ }^{4}$ Palaeontology, Geobiology and Earth Archives Research Centre, School of Biological, Earth and Environmental Sciences, University of New South Wales, Sydney, New South Wales, Australia. ${ }^{5}$ GNS Science, Wairakei, New Zealand. ${ }^{6}$ National Institute of Water and Atmospheric Research, Auckland, New Zealand. ${ }^{7}$ Cornell Tree Ring Laboratory, Department of Classics, Cornell University, Ithaca, New York 14853, USA. ${ }^{8}$ National Institute of Water and Atmospheric Research, Wellington, New Zealand. ${ }^{9}$ Department of Earth System Science, University of California, Irvine, California, USA. *email: alan.hogg@waikato.ac.nz
} 
reasons. First, deep, ${ }^{14} \mathrm{C}$-depleted groundwater is most unlikely to have affected the Pureora site, as it lies at $550 \mathrm{~m}$ above sea level ${ }^{5}$, in a separate catchment from that of the Waikato River, and is $\sim 300 \mathrm{~m}$ above and $20 \mathrm{~km}$ distant from the Waikato River at its nearest point. Second, the site is $\sim 200 \mathrm{~m}$ above the level of Lake Taupo and lies west of the watershed between it and the Taupo basin. Groundwater at the site is sourced from local rainfall $\left(1.8 \mathrm{~m}\right.$ of rainfall per year $\left.{ }^{5}\right)$. Third, the Pureora area also shows no traces of young faulting 12 that could have channelled putative magmatic $\mathrm{CO}_{2}$. Fourth, the mechanism of gaseous exchange to introduce ${ }^{14} \mathrm{C}$-depleted carbon into groundwater at the Pureora site is most unlikely. Groundwater flow at the site will be dominated by vertically downwards flow of rainfall recharge from the soil layers to deeper units and thus atmospheric $\mathrm{CO}_{2}$ must dominate carbon dioxide flux at the site. The notion that magmatic carbon could be introduced into groundwater of the Pureora site from magmatic sources beneath Taupo volcano (or anywhere in the central North Island), or somehow be introduced (against gravity) from the Waikato River water, is implausible.

HDK18 state that in the Pureora tanekaha tree-ring record, ${ }^{14} \mathrm{C}$ levels plateaued or declined as the eruption approached (p. 5,

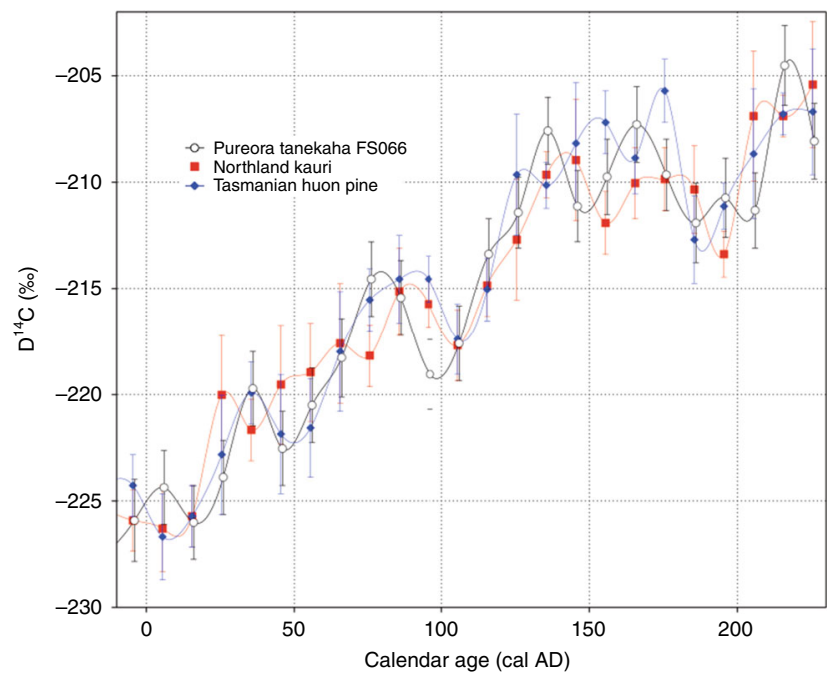

Fig. 1 Comparisons of radiocarbon concentrations from New Zealand and Tasmania trees. Radiocarbon concentration ( $D^{14} C, 1 \sigma$ error bars) plotted against calendar age for the Pureora tanekaha tree $\mathrm{FSO}^{4} 6^{4}$ together with Northland kauri ${ }^{14}$ and Tasmanian huon pine ${ }^{15}$. It should be noted that the vertical axis title in HDK18's Fig. 3 is incorrect-it should read $D^{14} \mathrm{C}$, as above, not $\Delta{ }^{14} \mathrm{C}$, which is age-corrected ${ }^{14} \mathrm{C}$ concentration
Fig. 3 caption), and that after $\sim 125$ years (Fig. 3a), linear relationships with the actual tree age broke down: the tree continued to grow but ${ }^{14} \mathrm{C}$ ages of the newly accreted wood were static (p. 4). However, the fitting of straight-line functions to ${ }^{14} \mathrm{C}$ concentrations is meaningless, as non-linearity in ${ }^{14} \mathrm{C}$ levels is universally recognised and underpins international calibration curves (e.g., SHCal13 ${ }^{13}$ ) and wiggle matching for age correlations ${ }^{4}$. Here we re-plot the Pureora tanekaha ${ }^{14} \mathrm{C}$ data against known calendar-age data from Northland (northernmost North Island) kauri ${ }^{14}$ and Tasmanian huon pine (Lagarostrobos franklinii) ${ }^{13,15}$ (Fig. 1). Although there is a general decline in ${ }^{14} \mathrm{C}$ levels towards the time of death of the Pureora tanekaha tree (spanning $\sim 50$ years; Fig. 1), the contemporaneous kauri and huon pine ${ }^{14} \mathrm{C}$ levels similarly decline, independent of any Taupo-proximal magmatic $\mathrm{CO}_{2}$ emissions. What HDK18 assert as evidence for isotopic dilution is simply a ${ }^{14} \mathrm{C}$ wiggle in atmospheric ${ }^{14} \mathrm{C}$ common to all three data sets.

In addition, HDK18 (Fig. 3a) propose a trend of lowered ${ }^{14} \mathrm{C}$ levels for $\sim 125$ years before the Taupo eruption. If correct, one would expect wiggle matching to derive a younger date for the eruption if the ${ }^{14} \mathrm{C}$ data from this 125 -year interval were excluded from the wiggle matching. We thus divided the Pureora tanekaha dates into two sets (Table 1): an inner fraction, i.e., dates in the range $125.5-245.5$ years before the eruption that HDK18 consider is linear with tree age, and an outer fraction, i.e., dates in the range 5.5-115.5 years before the eruption that HDK1 8 claim to be nonlinear as a result of ${ }^{14} \mathrm{C}$ dilution. The two sets were then wiggle-matched against $\mathrm{SHCal13}{ }^{13}$. The two sets considered separately give statistically identical model eruption dates both to each other and to the full 250-year dataset.

HDK18's analysis of the Pureora tanekaha tree $\delta^{13} \mathrm{C}$ record is flawed for two reasons. First, the Pureora tanekaha did not have at least 50 inner rings sampled, hence the lack of the so-called juvenile effect (increasing $\delta^{13} \mathrm{C}$ values as a juvenile: e.g., Supplementary Fig. 1), which will have influenced the shape of the $\delta^{13} \mathrm{C}$ record. Second, the Pureora tanekaha $\delta^{13} \mathrm{C}$ data, stated as anomalously high by HDK18, were obtained from the a-cellulose wood fraction with the $\mathrm{CO}_{2}$ produced by a through-flow combustion system, which together displace mean $\delta^{13} \mathrm{C}$ data to less negative values over those from the whole-wood fraction used by HDK18 by $2 \%$ (Supplementary Table 1 and Supplementary Note 1). HDK18's further statement that the Pureora tanekaha $\delta^{13} \mathrm{C}$ measurements are significantly higher than those of New Zealand forest trees (p. 4) is also not correct. For example, the outermost Pureora tanekaha rings yield cellulose $\delta^{13} \mathrm{C}$ values $\sim 2 \%$ o lower than the outermost rings from a kauri tree (e.g., Supplementary Fig. 1). The Pureora tanekaha $\delta^{13} \mathrm{C}$ values are

Table 1 Impact on the Taupo eruption date estimate

\begin{tabular}{|c|c|c|c|c|c|}
\hline $\begin{array}{l}\text { Wiggle match (utilising SHCal13 } \\
\text { calibration curve) }\end{array}$ & $\begin{array}{l}\text { No. of } \\
\text { analyses }\end{array}$ & $\begin{array}{l}\text { Wk centre ring (years } \\
\text { before eruption) }\end{array}$ & $\begin{array}{l}\text { Calendar age range (Mean } \\
\text { cal. age) (CE, } 95.4 \% \text { prob.) }\end{array}$ & $A m^{b}(\%)$ & $\begin{array}{l}\text { A }<60^{c} \\
\left(\text { Outliers }^{d}\right)(\%)\end{array}$ \\
\hline $\begin{array}{l}\text { Wk Pureora tanekaha }{ }^{14} \mathrm{C} \text { ages }>125 \\
\text { years before last extant tree ring and } \\
\text { eruption }\end{array}$ & 12 & $125.5-245.5$ & $220-240(230 \pm 10)$ & 89.9 & $4(4)$ \\
\hline $\begin{array}{l}\text { Wk Pureora tanekaha }{ }^{14} \mathrm{C} \text { ages }<125 \\
\text { years before last extant tree ring and } \\
\text { eruption }\end{array}$ & 13 & $5.5-115.5$ & $224-241(233 \pm 8)$ & 100.0 & $4(4)$ \\
\hline All Wk Pureora tanekaha ${ }^{14} \mathrm{C}$ ages & 25 & $5.5-245.5$ & $226-238(232 \pm 6)$ & 98.7 & $8(8)$ \\
\hline
\end{tabular}

Impact on the Taupo eruption date estimate as a result of dividing the 250 -year Wk Pureora tanekaha ${ }^{14} \mathrm{C}$ data series into two sets: an inner fraction, i.e., dates in the range $125.5-245.5$ years before the eruption that HDK18 consider is linear with tree age, and an outer fraction, i.e., dates in the range $5.5-115.5$ years before the eruption that HDK18 claim to be nonlinear as a result of ${ }^{14} \mathrm{C}$ dilution eruption that HDK18 consider is linear with tree age, and
aRing numbers from Hogg et al. ${ }^{4}$ (Table 1 in their study)

bModel agreement index. The agreement for the model as a whole. Ideally, the value should be $\sim 100 \%$ and should be $>60 \%$ (a threshold value close to the $5 \%$ confidence levels in a $\chi^{2}$-test). No reservoir offset function (Delta_R) applied

'Percentage of individual dates where the agreement index is below $60 \%$

dPercentage outliers, where an outlier, detected by 'outlier analysis', has a posterior probability of $>0.05$ (prior probability of a date being an outlier set at 0.05 ) 
neither anomalously high nor do they reflect any magmatic carbon input.

In conclusion, HDK18's proposal ${ }^{3}$ that the Taupo eruption is decades to centuries younger than $232 \pm 10 \mathrm{CE}$ is unsound. Although ${ }^{14} \mathrm{C}$-depleted materials are associated with magmatic degassing ${ }^{11}$, the context and consistency of any radiocarbon dates indicate whether a robust and accurate age estimate has been attained. The 250 -year ${ }^{14} \mathrm{C}$ wiggle-match against $\mathrm{SHCal13}$ presented here reinforces the view that $232 \pm 10 \mathrm{CE}^{4}$ remains the most accurate and precise age estimate for the Taupo eruption, and we conclude there is no evidence for anomalously older ages near the Taupo volcano. We re-assert that radiocarbon wiggle matching to refine volcanic event chronologies, especially where sequential ${ }^{14} \mathrm{C}$ dates and Bayesian modelling form the basis of the event timing, remains an accurate and invaluable dating tool.

\section{Data availability}

All data generated for this study are included in Supplementary Table 1. All other data plotted are from the relevant published and cited papers.

Received: 26 December 2018; Accepted: 28 August 2019; Published online: 11 October 2019

\section{References}

1. Wilson, C. J. N. \& Walker, G. P. L. The Taupo eruption, New Zealand, I. General aspects. Philos. Trans. Roy. Soc. Lond. A314, 199-228 (1985).

2. Lowe, D. J., Newnham, R. M., McFadgen, B. G. \& Higham, T. F. G. Tephras and New Zealand archaeology. J. Archaeol. Sci. 27, 859-870 (2000).

3. Holdaway, R. N., Duffy, B. \& Kennedy, B. Evidence for magmatic carbon bias in ${ }^{14} \mathrm{C}$ dating of the Taupo and other major eruptions. Nat. Commun. 9, 4110 (2018).

4. Hogg, A. G., Lowe, D. J., Palmer, J. G., Boswijk, G. \& Bronk Ramsey, C. J. Revised calendar date for the Taupo eruption derived by ${ }^{14} \mathrm{C}$ wiggle-matching using a New Zealand kauri ${ }^{14} \mathrm{C}$ calibration data set. Holocene 22, 439-449 (2012).

5. Clarkson, B. R., Patel, R. N. \& Clarkson, B. D. Composition and structure of forest overwhelmed at Pureora, central North Island, New Zealand, during the Taupo eruption (c. AD 130). J. Roy. Soc. N. Z. 18, 417-436 (1988).

6. Palmer, J. G., Ogden, J. \& Patel, R. N. A 426-year floating tree-ring chronology from Phyllocladus trichomanoides buried by the Taupo eruption at Pureora, central North Island, New Zealand. J. Roy. Soc. N. Z. 18, 407-415 (1988).

7. Lowe, D. J. \& de Lange, W. P. Volcano-meteorological tsunamis, the $c$. AD 200 Taupo eruption (NZ) and the possibility of a global tsunami. Holocene 10, 401-407 (2000).

8. Froggatt, P. C. \& Lowe, D. J. A review of late Quaternary silicic and some other tephra formations from New Zealand: their stratigraphy, nomenclature, distribution, volume, and age. N. Z. J. Geol. Geophys. 33, 89-109 (1990).

9. Grant-Taylor, T. L. \& Rafter, T. A. New Zealand natural radiocarbon measurements I-V. Radiocarbon 5, 118-162 (1963).

10. Lowe, D. J., Blaauw, M., Hogg, A. G. \& Newnham, R. M. Ages of 24 widespread tephras erupted since 30,000 years ago in New Zealand, with re-evaluation of the timing and palaeoclimatic implications of the late-glacial cool episode recorded at Kaipo bog. Quat. Sci. Rev. 74, 170-194 (2013).

11. Beavan-Athfield, N. R., McFadgen, B. G. \& Sparks, R. J. Environmental influences on dietary carbon and ${ }^{14} \mathrm{C}$ ages in modern rats and other species. Radiocarbon 43, 7-14 (2001)
12. Leonard, G. S., Begg, J. G. \& Wilson, C. J. N. (compilers). Geology of the Rotorua area. Scale 1:250,000. (Institute of Geological \& Nuclear Sciences, Lower Hutt, 2010).

13. Hogg, A. G. et al. SHCal13 Southern Hemisphere calibration, 0-50,000 years cal BP. Radiocarbon 55, 1889-1903 (2013).

14. Hogg, A., Palmer, J., Boswijk, G. \& Turney, C. High-precision radiocarbon measurements of tree-ring dated wood from New Zealand: 195 BC-AD 995. Radiocarbon 53, 529-542 (2011).

15. Zimmerman, S., Guilderson, T., Buckley, B. \& Cook, E. Extension of the Southern Hemisphere atmospheric radiocarbon curve, $2120-850$ years BP: results from Tasmanian Huon pine. Radiocarbon 52, 887-894 (2010).

\section{Acknowledgements}

C.J.N.W. acknowledges support from the ECLIPSE programme funded by the New Zealand Ministry of Business Innovation and Employment. D.J.L. acknowledges support from the 'Hidden Hazards' project (15/U713) funded by The Earthquake Commission and Waikato Regional Council.

\section{Author contributions}

A.G.H., S.W.M. and J.S. developed the radiocarbon dating aspects of the paper. A.G.H drafted Fig. 1, undertook the wiggle matching summarised in Table 1, and obtained the tree-ring samples utilised for $\delta^{13} \mathrm{C}$ analysis in Supplementary Table 1. C.J.N.W. and D.J.L. provided volcanological expertise, analysed the ${ }^{14} \mathrm{C}$ dataset on Taupo eruptives and, together with A.G.H., C.S.M.T., A.M.L. and P.W., played a major part in drafting the submission. S.B. and J.B. undertook $\delta^{13} \mathrm{C}$ analysis of the tree-ring samples and, with A.M.L., helped to interpret the stable isotope results. Specific inputs came from J.G.P. (dendrochronology), P.W. (groundwater) and F.P. (bone dating). All authors contributed to development of the final text.

\section{Competing interests}

The authors declare no competing interests.

\section{Additional information}

Supplementary information is available for this paper at https://doi.org/10.1038/s41467 019-12532-8.

Correspondence and requests for materials should be addressed to A.G.H.

Peer review information Nature Communications thanks Aldo Romero and Markus Morgenstern for their contribution to the peer review of this work.

Reprints and permission information is available at http://www.nature.com/reprints

Publisher's note Springer Nature remains neutral with regard to jurisdictional claims in published maps and institutional affiliations.

Open Access This article is licensed under a Creative Commons Attribution 4.0 International License, which permits use, sharing, adaptation, distribution and reproduction in any medium or format, as long as you give appropriate credit to the original author(s) and the source, provide a link to the Creative Commons license, and indicate if changes were made. The images or other third party material in this article are included in the article's Creative Commons license, unless indicated otherwise in a credit line to the material. If material is not included in the article's Creative Commons license and your intended use is not permitted by statutory regulation or exceeds the permitted use, you will need to obtain permission directly from the copyright holder. To view a copy of this license, visit http://creativecommons.org/ licenses/by/4.0/.

(c) The Author(s) 2019 